\title{
熔鋼による下注用棟瓦の熔蝕機構，並びに 高アルミナ質砂の発生原因について
}

造塊用粘土質耐火物に関する研究（第 5 報）

佐々木茂 式

（日本鋼管，技術研究所）

\author{
On the Mechanism of the Erosion of Fire-Clay Bricks for \\ Bottom Casting Caused by the Flow of Molten Steel, and the \\ Cause of the Occurence of Aluminous Sand \\ Studies on the Fire Clay Brick Refractories for Casting Pit, V. \\ By \\ Shigeichi SASAKI \\ (Technical Research Institute, Japan Steel and Tube Corp., Kawasaki)
}

\begin{abstract}
To the author's knowledge there exists no established explanation on the mechanism of the erosion of the bricks used in the equipments of bottom casting for producing conventional carbon steel with basic open-hearth furnace, and also with converter. Moreover, while it is generally assumed that the occurence of aluminous sand is very likely due to the erosion of the bricks by molten steel, in particular to the reaction of the reducing $\mathrm{SiO}_{2}$ of fire-clay bricks by $\mathrm{Mn}$ of molten steel, whose concentration is closely related to the deoxidizing reaction, the effective method of preventing the sand has not been known.

From the results of the previous investigations ${ }^{1)}$ the author concluded that the erosion of the bricks is mainly due to the oxides of slaggy matter contained in flowing molten steel, and also the occurence of aluminous sand is likely due to another causes. This paper contains the results of the mathematical-theoretical as well as the experimental studies carried out to prove more clearly the author's conception.

[Received May 8, 1962]
\end{abstract}

\section{I. 緒 言}

熔鋼による煉瓦の熔蝕機構，熔蝕と砂症，あるいは酸 化物系非金属介在物の関連性について従来から有益な研 究の発表を見受けるとてろであるが，てれらに関する定 説というものがない，殊に高アルミナ質砂の成因につい ては，熔鋼による煉瓦の熔蝕がその最も有力な因子とし てとりあげられてきたにもかかわわらずそれに対する説明 は不確定な要素を少なからず含んでいると言ってよい.

著者は前報1において述べた塩基性平炉および転炉の 両製鋼造塊において試験調查をなした結果からして，下 注用のノズルより下流の各煉瓦の熔蝕は熔鋼流中の浮遊 微㳯の挙動とその煉瓦におよぼす作用に特に密接な関係 をもっており，また高アルミナ質砂も単に熔銅による煉 瓦の化学的熱的な侵蝕で発生しないであろうと予想され たので,さうに熔鋼による熔蝕の機構, 並びに高アルミ ナ質砂の成因について次のように考察したものである.

ここにアルミナ質砂と称するのは, ガラス, ムライト およびュランダム粒晶が集合状態で認められるものと， コランダム粒晶が雲状に鋼中に分布するいわゆる雲状コ
ランダム砂 (Cloudy corundum sand) ${ }^{2)}$ の 2 種を指す ことにしたい，てのほが耐火物を根源とするとみなさ れているものに一般的な砂, あるいは砂㾟（大きさ10\% 以上), 砂くいがある.乙れらは外観, 分布状馝, 形状 大きさ，性状などの点から区別されているものである が,広義にはアルミナ質砂を一般の砂に包含させうるし， またてれらをばすべて酸化物系非金属介在物とみなして 差支えないと考える。

II. 熔鋼中浮遊の遊離 $(\mathrm{MnO}),(\mathrm{FeO}),(\mathrm{Mn}$, $\mathrm{Fe})_{2} \mathrm{SiO}_{4},(\mathrm{Mn}, \mathrm{Fe}) \mathrm{SiO}_{4}$ の煉瓦への作用

一般にグロッグ粘土質耐火物の主構成鉱物相は, 配合 粘土の種類, 配合割合, あるいはまた焼成条件などによ って相異するが，次のように考えることができる．

$$
\begin{array}{r}
{\left[\left\{\left(m \cdot \mathrm{Al}_{2} \mathrm{O}_{3} \cdot 2 \mathrm{SiO}_{2}+\mathrm{SiO}_{2}\right)\right.\right.} \\
厶 \text { ムイト分散相 }
\end{array}
$$

あるいは

$\left[\left(n \cdot \mathrm{Al}_{2} \mathrm{O}_{3} \cdot 2 \mathrm{SiO}_{2}+\text { glass matrix }\right)_{\text {clay }}+x \cdot\left(\mathrm{SiO}_{2}\right)_{\mathrm{Q}}\right]$ $\left(\mathrm{SiO}_{2}\right)_{\mathbf{Q}} \cdots$ 遊離石英 
また，蝋石粘土質耐火物の場合は同様に主鉱物相を次 のように考觉うるだろう。

$\left[\left(\mathrm{Al}_{2} \mathrm{O}_{3} \cdot 4 \mathrm{SiO}_{2}+\text { ガラスマトリックス }\right)_{\mathrm{pyro}}\right.$ $\left.+x \cdot\left(\mathrm{SiO}_{2}\right)_{\mathrm{Q}}\right]$

あるいは

$\left[\left(\mathrm{Al}_{2} \mathrm{O}_{3} \cdot 4 \mathrm{SiO}_{2}+\text { ガラスマトリックス }\right)_{\text {pyro. }}\right.$.

$+\left\{\left(l \cdot \mathrm{Al}_{2} \mathrm{O}_{3} \cdot 2 \mathrm{SiO}_{2}+\mathrm{SiO}_{2}\right)_{\text {clay }}+x \cdot\left(\mathrm{SiO}_{2}\right)_{\mathrm{Q}}\right]$

遊離石英は, 本研究で対象とした各煉瓦試料の場合に 約 $6.0 \sim 30.0 \%$ の含量範囲であった.

このような釷物相からなる煉瓦に遊離の $(\mathrm{MnO})$, $(\mathrm{FeO})$ が作用することにより生成する熔蝕層は, 次の 2 つの場合を考えうる.

i) $(\mathrm{Mn}, \mathrm{Fe}) \mathrm{O}-\mathrm{SiO}_{2}$ 系化合物の生成とガラス化

ii) $(\mathrm{Mn}, \mathrm{Fe}) \mathrm{O}-\mathrm{Al}_{2} \mathrm{O}_{3}-\mathrm{SiO}_{2}$ 系化合物の生成とガラ ス化

またマンガン鉄珪酸塩の作用する場合についても同様に 考えうるが ( $\mathrm{Mn}, \mathrm{Fe}) \mathrm{O}$ の作用の場合と相異している 点はその作用の激しいほど熔蝕層の $\mathrm{Al}_{2} \mathrm{O}_{3} / \mathrm{SiO}_{2}$ 比が低 くなってゆくてとである。

$\mathrm{SiO}_{2} 75 \sim 55 \%, \mathrm{Al}_{2} \mathrm{O}_{3}$ 25 45\% の粘土質煉瓦表面に 作用することにより生成する鉱物の主なものは， $\mathrm{MnO}$ $\mathrm{Al}_{2} \mathrm{O}_{3}-\mathrm{SiO}_{2}$ および $\mathrm{FeO}-\mathrm{Al}_{2} \mathrm{O}_{3}-\mathrm{SiO}_{2}$ 両二元状態図か ら, $\mathrm{MnO}-\mathrm{FeO}-\mathrm{Al}_{2} \mathrm{O}_{3}-\mathrm{SiO}_{2}$ 系のガラス, ムライト, Spessartite $\left(3 \mathrm{MnO} \cdot \mathrm{Al}_{2} \mathrm{O}_{3} \cdot 3 \mathrm{SiO}_{2}\right), 2 \mathrm{MnO} \cdot 2 \mathrm{Al}_{2} \mathrm{O}_{3}$ • $5 \mathrm{SiO}_{2}$, トリジマイト, Hercynite $\left(\mathrm{FeO} \cdot \mathrm{Al}_{2} \mathrm{O}_{3}\right)$, ファヤ ライト $\left(2 \mathrm{FeO} \cdot \mathrm{SiO}_{2}\right)$ などであるてとがわかる。またア ルミナ分の特に高い煉瓦の場合にコランダムの生成も考 えられる。

熔蝕層の検鏡結果によれば,りムド鋼の場合において コランダムを全く認めなかったが，乙の点から $(\mathrm{MnO})$, $(\mathrm{FeO})$ あるいは鉄マンガン珪酸塩の作用だけではコラ ンダムを発生することのないてとが推定される。したが ってまた,キルド鋼の場合の熔蝕層に多数のムライト晶， ガラスと同時に認められたコランダム粒晶は $(\mathrm{MnO})$, ( $\mathrm{FeO})$ あるいは鉄マンガン珪酸塩の作用で発生したも のであるとは考元難い，ムライト分散相中にきわめて微 細な $\gamma-\mathrm{Al}_{2} \mathrm{O}_{3}$ の含有について考えうるであろう高アル そナ質のグロッグ粘土質棟瓦の場合に，遊離の $(\mathrm{MnO})$, $(\mathrm{FeO})$ の作用だけで熔蝕層にコランダム晶を認めるて とが予想される。しかし仮にてのような作用か圮るとし ても熔蝕層の化学組成はコランダムが生成し難い $\mathrm{MnO}$ $\mathrm{FeO}-\mathrm{Al}_{2} \mathrm{O}_{3}-\mathrm{SiO}_{2}$ 系の低熔融化合物にほぼ該当するの で,リムド鋼の熔蝕首は最終的にはコランダム晶の検出 されない完全なガラスか，あるいはムライトを分布する ガラスであるにすぎないのであろう.

III. 熔鋼中 $[\mathrm{Mn}],[\mathrm{C}]$ による煉瓦中 $\mathrm{SiO}_{2}$ 分の還元 に基因する棟瓦侵蝕，コランダム晶発生
キルド鋼注入の場合，殊に高 $\mathrm{Mn}$ であるキルド鋼の 場合に熔鋼中 $[\mathrm{Mn}],[\mathrm{Si}]$ の平衡関係から $[\mathrm{Mn}]$ によ る煉瓦中の $\mathrm{SiO}_{2}$ 分の還元反応か圮ること, ての還元反 応で侵蝕か圮きて煉瓦を根源とするコランダム晶を発生 しコランダム晶を熔蝕層に認めるようになるてと，同様 に浮上スカムにも同根因のコランダム晶を認めるように なること，などが予想される，また $[\mathrm{Fe}]$ による還元に ついても同様であり，さらに投入脱酸劑，殊に Al によ る還元と侵蝕が考光られている，熔鋼による煉瓦の侵蝕 を明らかにするためには，乙れらの点についても検討す る必要があり，煉瓦中の $\mathrm{SiO}_{2}$ 分を遊離クリストバライ トとみなして次の各反応式の遊離エネルギー $\Delta \mathrm{F}^{\circ}$ を算 定して考察した。

$$
\begin{gathered}
1 / 2\left(\mathrm{SiO}_{2}\right)_{\text {crist. }}+[\mathrm{Mn}]=(\mathrm{MnO})_{l, s}+1 / 2[\mathrm{Si}] \\
\ldots \ldots \ldots \ldots(1) \\
1 / 2\left(\mathrm{SiO}_{2}\right)_{\text {crist. }}+[\mathrm{Fe}]=[\mathrm{FeO}]+1 / 2[\mathrm{Si}] \\
\ldots \ldots \ldots \ldots(2) \\
1 / 2\left(\mathrm{SiO}_{2}\right)_{\text {crist. }}+2 / 3[\mathrm{Al}]=1 / 3\left(\mathrm{Al}_{2} \mathrm{O}_{3}\right)_{s}+1 / 2[\mathrm{Si}] \\
\cdots \cdots \cdots \cdots(3) \\
1 / 2\left(\mathrm{SiO}_{2}\right)_{\text {crist. }}+[\mathrm{C}]=\mathrm{CO}+1 / 2[\mathrm{Si}]
\end{gathered}
$$

([Mn], $[\mathrm{Si}],[\mathrm{Al}],[\mathrm{C}]$ を熔鉄中百分率を表わす) 遊離エネルギーの計算結果から 註1)，造塊時の熔鋼温 度 $1550^{\circ} \sim 1600^{\circ} \mathrm{C}$ では(1)反応の進行の可能性は小さく, また(2)反応も進行し難く，したがって熔鋼中の $[\mathrm{Mn}]$ に よる煉瓦中 $\mathrm{SiO}_{2}$ の還元は起り難いこと, てれに対して $[\mathrm{C}],[\mathrm{Al}]$ による $\mathrm{SiO}_{2}$ 還元の方が起りうるとと，がわ かる.すなわち, $[\mathrm{Mn}],[\mathrm{Fe}]$ による煉瓦中の $\mathrm{SiO}_{2}$ の 還元反応は造塊時の熔鋼温度で起り難い.

しかし，次のように 2 反忘の同時平衡として考えると $[\mathrm{Mn}],[\mathrm{Fe}]$ による $\mathrm{SiO}_{2}$ の還元反応進行の可能性がで てくる.

$$
\begin{aligned}
&\left(\mathrm{SiO}_{2}\right)_{\text {crist. }}+2[\mathrm{Mn}]=[\mathrm{Si}]+2(\mathrm{MnO})_{l} l \\
& 2(\mathrm{MnO})_{l}+[\mathrm{C}]= 2[\mathrm{Mn}]+2 \mathrm{CO} \\
&(\mathrm{SiO})_{\text {crist. }}+2[\mathrm{C}]=[\mathrm{Si}]+2 \mathrm{CO} \\
&\left(\mathrm{SiO}_{2}\right)_{\text {crist. }}+2[\mathrm{Fe}]=[\mathrm{Si}]+2[\mathrm{FeO}] \\
& 2[\mathrm{FeO}]+2[\mathrm{C}]= 2[\mathrm{Fe}]+2 \mathrm{CO} \\
&(\left.\mathrm{SiO}_{2}\right)_{\text {crist. }}+2[\mathrm{C}]=[\mathrm{Si}]+2 \mathrm{CO}
\end{aligned}
$$

との場合にも $[\mathrm{C}]$ による $(\mathrm{MnO}),(\mathrm{FeO})$ の還元が進 むととにより初めて $[\mathrm{Mn}],[\mathrm{Fe}]$ による $\mathrm{SiO}_{2}$ 還元が 進行するのであり，最終的には [C] による $\mathrm{SiO}_{2}$ の還 元であって熔鋼による $\mathrm{SiO}_{2}$ 還元は $[\mathrm{C}],[\mathrm{Al}]$ による $\mathrm{SiO}_{2}$ の還元の問題に帰着する.

乙の熔鋼の溶解 $[\mathrm{Mn}],[\mathrm{Al}],[\mathrm{C}]$ の煉瓦中 $\mathrm{SiO}_{2}$ 亿及 ぽす作用については，単に $\Delta \mathrm{F}^{\circ}$ の数值上から断定でき ない問題でもあるが，低マンガンキルド鋼注入の煉瓦熔 蝕層を検鏡したところによると，煉瓦に既存する石英晶 が侵蝕されずに比較的に多く明瞭に検出されたという事 
実からしても煉瓦中 $\mathrm{SiO}_{2}$ の還元は起きていないこと， また強還元作用をもつ $[\mathrm{C}] ，[\mathrm{Al}]$ 亿よっても還元は容 易に起きていないと推定されるとてろである.

したがって，検鏡でみとめられた煉瓦熔蝕層中のコラ ンダム晶の大部分は煉瓦一熔鋼間の反応による産物では なくして投入 $\mathrm{Al}$ の脱酸反応生成物が主体であると推論 され，てのととは後項で述べる介在物，あるいは浮遊微 㳯の炉内一注入間における成分とその変化について調べ た結果を参照するととによりいっそう明瞭となる。

\section{IV. 熔鋼による煉瓦表面の熔融}

$\mathrm{SiO}_{2} \quad 75 \sim 60 \% ， \mathrm{Al}_{2} \mathrm{O}_{3}$ 25 40\% の粘土質煉瓦に $1550^{\circ} \mathrm{C}$ 以上の高温の熔鋼が接する際に熱的作用のみで 煉瓦表面に熔融化が起り，またてのためにコランダム晶 が棟瓦熔蝕首に生成するかどうかという点問題になる。

$\mathrm{SiO}_{2}-\mathrm{Al}_{2} \mathrm{O}_{3}$ 二元系によると $\mathrm{SiO}_{2} 94.5 \%, \mathrm{Al}_{2} \mathrm{O}_{3}$ $5.5 \%$ 飞 $1545^{\circ} \mathrm{C}$ の共晶点をもつが，てれからムライト とクリストバライトの共晶からなる熔融表面層の形成し 易いととが考えられる．また煉瓦中のグロッグ粒間の低 熔融性ガラス質マトリックスに熱的熔融の起ることが考 えられる。しかし，コランダム晶の生成傾向について二 元系態図からは全く予想できない。

煉瓦熔蝕首について検鏡した結果によると，熔蝕層に 認められたガラスは $\mathrm{SiO}_{2}-\mathrm{Al}_{2} \mathrm{O}_{3}$ 成分系のガラスに比べ て高い屈折率をもつものが多いが，てれらの点から棟瓦 の熔蝕主因は単なる熔融化にはないととを推定できる。

\section{V. 熔鋼中の浮遊微涬の挙動}

煉瓦の熔蝕，ことにコランダム晶を分布する場合の熔 蝕の主因は，前述した諸点から単なる熔鋼による化学的 熱的作用にはなく浮遊微㳯の举動に密接な関係をもつこ とが考えられたので，砂疪に特に関連の深いアルミナの 場合を例にとり，アルミ投入量，投入アル之量の $\mathrm{Al}_{2} \mathrm{O}_{3}$ 当量, 同 $\mathrm{Al}_{2} \mathrm{O}_{3}$ 当量の粒子数, $\mathrm{Al}_{2} \mathrm{O}_{3}$ 粒子の大きさと 浮揚性, なぞについて調べ熔鋼中の $\mathrm{Al}_{2} \mathrm{O}_{3}$ 微涬の挙動 を追究した。

投入アルミの $\mathrm{Al}_{2} \mathrm{O}_{3}$ 当量, 同 $\mathrm{Al}_{2} \mathrm{O}_{3}$ 粒子の数と大き さ：熔鋼 $50 \mathrm{t}$ 亿対し $0.03 \%$ のアル之（以下 $\mathrm{Al}$ とす） を脱酸剤として投入する場合を考える。乙の $\mathrm{Al}$ の全部 か酸化して $\mathrm{Al}_{2} \mathrm{O}_{3}$ になると仮定すると，熔鋼に対する 重量比率ではきわめて微々たるものであるが，粒子数と しては次のように莫大な数になる.

投入 $\mathrm{Al}$ の酸化で生成する $\mathrm{Al}_{2} \mathrm{O}_{3}$ の容積, 重量 熔鋼 $50 \mathrm{t}$ の容積……….......... $V_{\mathrm{Fe}}=6.94 \mathrm{~m}^{3}$ Al $0.015 \mathrm{t}$ の容積……........... $\quad V_{\mathrm{Al}}=0.005_{5} \mathrm{~m}^{3}$

$\mathrm{Al} 0.015 \mathrm{t}$ 亿相当の $\mathrm{Al}_{2} \mathrm{O}_{3}$ 容積

$$
V_{\mathrm{Al}_{2} \mathrm{O}_{3}}=0.007_{6} \mathrm{~m}^{3}
$$

Al $0.015 \mathrm{t}$ 亿相当の $\mathrm{Al}_{2} \mathrm{O}_{3}$ 重量
生成 $\mathrm{Al}_{2} \mathrm{O}_{3}$ の粒子数 ( $M$ 個)

$$
\begin{array}{cccc}
d(\mathrm{~mm}) & 0.100 & 0.010 & 0.003 \\
M \text { (個) } & 14.3 \times 10^{9} & 14.3 \times 10^{12} & 5.2 \times 10^{14}
\end{array}
$$

ただし， $\mathrm{Al}_{2} \mathrm{O}_{3}$ 粒子を球状，平均粒子径を $d \mathrm{~mm}$ と おき $V_{\mathrm{Al}_{2} \mathrm{O}_{3}}=0.0076 \mathrm{~m}^{3}$ から算出した.

実際には，脱酸剤として投入する $\mathrm{Al}$ 全量が $\mathrm{Al}_{2} \mathrm{O}_{3}$ に酸化するてとなく $[\mathrm{Al}]$ あるいは $[\mathrm{AlN}]$ としても鋼 中に含まれ，したがって $\mathrm{Al}_{2} \mathrm{O}_{3}$ 粒子数は換算数量より 少なくなる. [Al] として鋼中に残存する量は投入 $\mathrm{Al}$ 量 の多少のみでなく脱酸法, 造塊法, さらにまた熔鋼の炭 素量, 鋼種などにより一定していないが, 例えば本研究 で対象とした低マンガンキルド鋼の場合に取鍋投入 $\mathrm{Al}$ 量 $0.04 \%$ に対して鋼中 [Al] は $0.006 \%$ 台であった.

$\mathrm{Al}$ 投入量の約 $15 \%$ が [Al] として鋼中に残留するに すぎず，その大部分は酸化して $\mathrm{Al}_{2} \mathrm{O}_{3}$ となり，また一 部は AlN となり鋼中に残留すると推察される.

仮に，投入 $\mathrm{Al}$ の中の約 $1 / 3$ のみが $\mathrm{Al}_{2} \mathrm{O}_{3}$ になると しても莫大な $\mathrm{Al}_{2} \mathrm{O}_{3}$ 粒子数には変りなく, 注入時に無 数の $\mathrm{Al}_{2} \mathrm{O}_{3}$ 粒が熔鋼中に浮遊しているてとが考えられ るわけである。

熔鋼中浮遊の微涬粒子の浮揚性 : 定盤煉瓦の熔蝕層お よびスカム中に検出されたコランダム粒晶は, 球形のほ かに短柱状のものもあり一定していないが，多くの場合 に球形粒状であった，粒サイズは平均径で 0.002 $0.050 \mathrm{~mm}$ 範囲であり, 約 $0.003 \mathrm{~mm}$ 前後の粒晶が最も 多くみとめられた。スカム中に検出された石英粒晶は板 粒状であり, 平均径で $0.09 \sim 0.18 \mathrm{~mm}$ 台のものが最も 多く, また 0.18 0.36 mm および 0.04 0.09 mm と いったやや大形と小形のものもみとめられた。

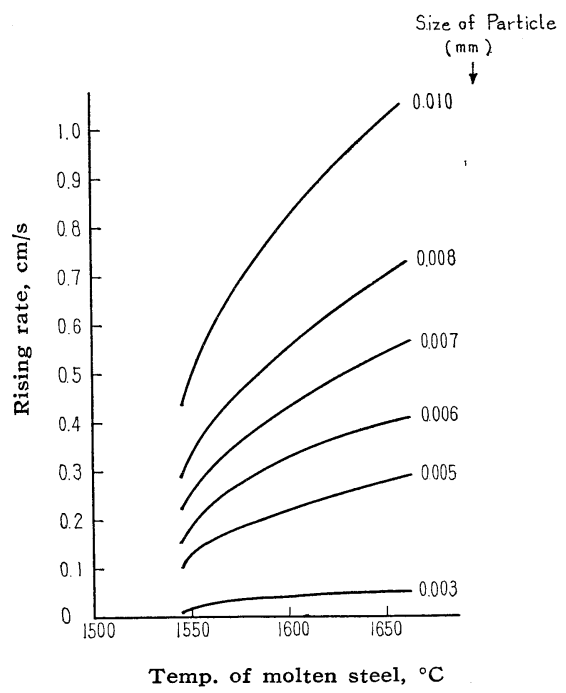

Fig. 1. Relation between rising rate, diameter of $\mathrm{Al}_{2} \mathrm{O}_{3}$ particle and temperature of molten steel by applying Stokes formula. 


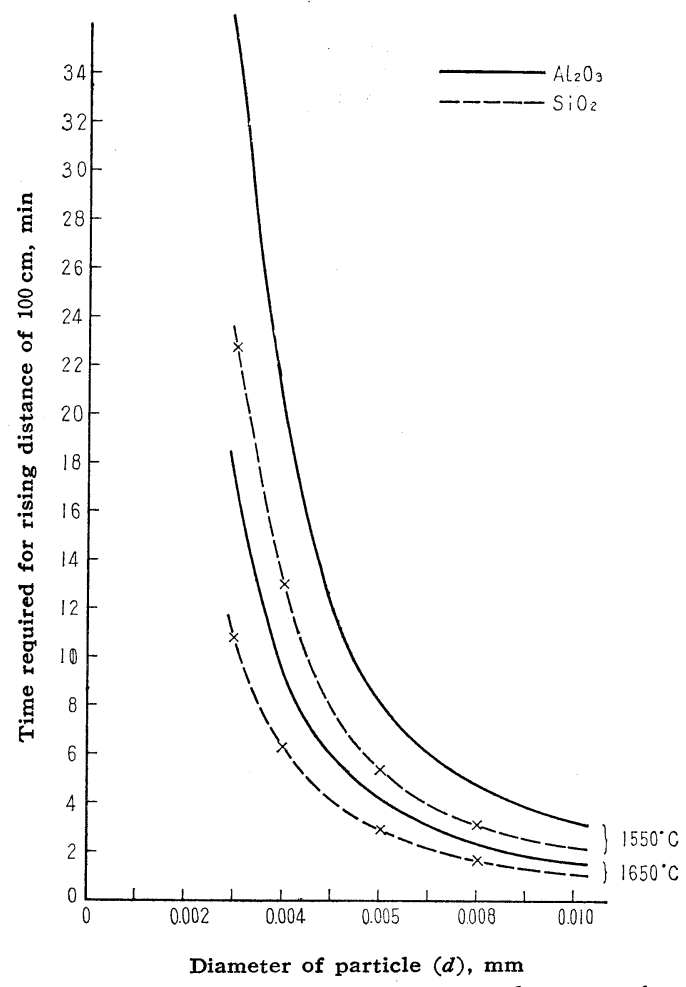

Fig. 2. Relation between rising time, diameter of a minute slaggy matter particle and temperature of molten steel.

Assuming viscosity of molten steel as follows. 0.031 poise at $1550^{\circ} \mathrm{C}$

0.015 " " $1650^{\circ} \mathrm{C}$

Stokes の式 $v=d^{2}\left(r_{e}-r_{m}\right) / 18 \cdot \eta \times g$ 汃 熔鋼温度 $1550^{\circ} \sim 1650^{\circ} \mathrm{C}$ 䇢囲にわたり $\mathrm{Al}_{2} \mathrm{O}_{3}$ 粒子について算定 した浮揚速度はきわめて小さく，例えば径 $0.003 \mathrm{~mm} の$ 場合で約 $0.02 \sim 0.05 \mathrm{~cm} / \mathrm{s}$ 台である (図一1). この粒子 浮揚速度から取鍋内で $100 \mathrm{~cm}$ の距離を浮揚するのに要 する時間を求め, 浮揚時間 (取鍋待時間), 粒径, 熔銅温 度の関係として図示したのが図一2である。

図一2 加ら使用する取鍋の容量の大小によっても浮遊 微溹には注入の各時期において量的質的な相異, 層別の 分布差が生ずること，粒径約 $0.003 \mathrm{~mm}$ 以下の粒晶は 大容量の取鍋 $(50 \sim 60 \mathrm{t})$ の場合に熔鋼面に浮上し切れ ないものもでるてと，などについて推定できる，後述す るように大容量の取鍋の場合に注入終期あるいは三定船 注入期に一，二定盤注入期に比べて浮遊微涬が量的に多 い傾向をもっていたという事実は恐らく上記の関係を一 因としているがためであろう.

$\mathrm{Al}_{2} \mathrm{O}_{3}$ 粒に比べて比重の小さい $\mathrm{SiO}_{2}$ の場合では, 図-2 のように $\mathrm{Al}_{2} \mathrm{O}_{3}$ に比べて浮揚し易い.しかし， この場合にも微細に熔鋼中に分散し浮遊する粒子の中に は熔鋼面にまで浮上し切れないものもでてくるだろう。 さらに微細な状態で分散すると考えられる $(\mathrm{MnO})$,
( $\mathrm{FeO})$ の場合では珪酸塩となり凝集と肥大の過程を経 て大形粒子とならない限り熔鋼中に浮遊し残留する傾向 がきわめて大きいであろう.

定盤棟瓦熔蝕層に粘着する $\mathrm{Al}_{2} \mathbf{O}_{3}$ 数量 : 定盤煉瓦の 熔蝕首の厚さを平均 $0.3 \mathrm{~mm}$ (検鏡結果に基づく) とお き, 粒径 $0.003 \mathrm{~mm} の \mathrm{Al}_{2} \mathrm{O}_{3}$ 粒子が定盤煉瓦内面に乙 の厚さだけ全面に粘着し覆うたと仮定して全粘着粒子数 を概算し, 酸化で生成する $\mathrm{Al}_{2} \mathrm{O}_{3}$ 数量に対する比率を 求めてみた。

その結果, 粘着する $\mathrm{Al}_{2} \mathrm{O}_{3}$ 粒子の全数は $8.6 \times 10^{11}$ $3.1 \times 10^{13}$ 個台であり, 酸化生成の全 $\mathrm{Al}_{2} \mathrm{O}_{3}$ の約 $6 \%$, $\mathrm{Al}_{2} \mathrm{O}_{3}$ の容積比で全体の約 $3 \%$ であるに過ぎないてとが わかった 註2)。乙の程度の量なら熔鋼中の $\mathrm{Al}_{2} \mathrm{O}_{3}$ 粒子 の浮揚性からみて取鍋内の熔鋼に浮遊残留してノズル以 下の下流にまで運ばれてゆくと考えて不合理でないよう に思う。

\section{VI. 浮遊微溹の作用による煉瓦熔蝕の状態}

湯道棟瓦の熔蝕が浮上し切れずに熔鋼流中に残留する 脱酸反応生成物である酸化物系浮遊微涬に特に深い関係 にあり, 煉瓦表層の熔融一微涬粘着一化学反応の過程を 経て起るとすれば，その熔蝕の状㦔は熔鋼流中に浮遊す る微涬の質的量的条件による影響を強くうけるととにな る.この好例はりムド, キルド両鋼種を注入した各湯道 煉瓦の熔蝕部に肉眼的顕微鏡的差異を明らかにみとめう るととである。

てのような影響をおよばすと考元られる浮遊微㳯の成 分的量的変化について，平炉，転炉のリムド，キルド鋼 の数チャージ分で炣内から注入終了までの間に採取した 鋼試料から温硝酸法で抽出した残渣の分析結果に基づき 調べてみた.さらに浮遊微㳯の成分的量的変化によって 起りうるであろう熔蝕の状態について考察した。

\section{（1）炉内一注入期間における酸化物系浮遊微涬の成} 分, 量的変化

浮遊微㳯の成分变化：出鋼直前の炉内における熔鋼 中の酸化物系微㳯，並びに出鋼一注入終了間における同 微㳯の主化学成分変化はそれぞれ図一 $3 \mathrm{~A}, \mathrm{~B}, \mathrm{C}, \mathrm{D}, \mathrm{E}$ 亿 示す通りである。

浮遊微澾の $(\mathrm{MnO}) /\left(\mathrm{SiO}_{2}\right),(\mathrm{FeO}) /\left(\mathrm{SiO}_{2}\right)$ の両比 は, リムド, キルドの両鋼種で同じように炉内, 出鋼, 注入と進行するとともに低下する傾向を示す．しかし， リムド鋼ではたと兄 $\left(\mathrm{Al}_{2} \mathrm{O}_{3}\right) /\left(\mathrm{SiO}_{2}\right)$ 比が大きくなって も $(\mathrm{MnO}) /\left(\mathrm{SiO}_{2}\right),(\mathrm{FeO}) /\left(\mathrm{SiO}_{2}\right)$ 両比は零あるいはそ の近くまで低下することがないし，また $\left(\mathrm{Al}_{2} \mathrm{O}_{3}\right) /$ $\left(\mathrm{SiO}_{2}\right)$ 比は 3.0 以上にはならぬ.乙れ対して脱酸剤 あるいは粒度調整剤の目的でアルミニウムを多量に使用 するキルド鋼では $(\mathrm{MnO}) /\left(\mathrm{SiO}_{2}\right),(\mathrm{FeO}) /\left(\mathrm{SiO}_{2}\right)$ 両比 の著しい低下傾向とともに 3.0 以上の $\left(\mathrm{Al}_{2} \mathrm{O}_{3}\right) /\left(\mathrm{SiO}_{2}\right)$ 

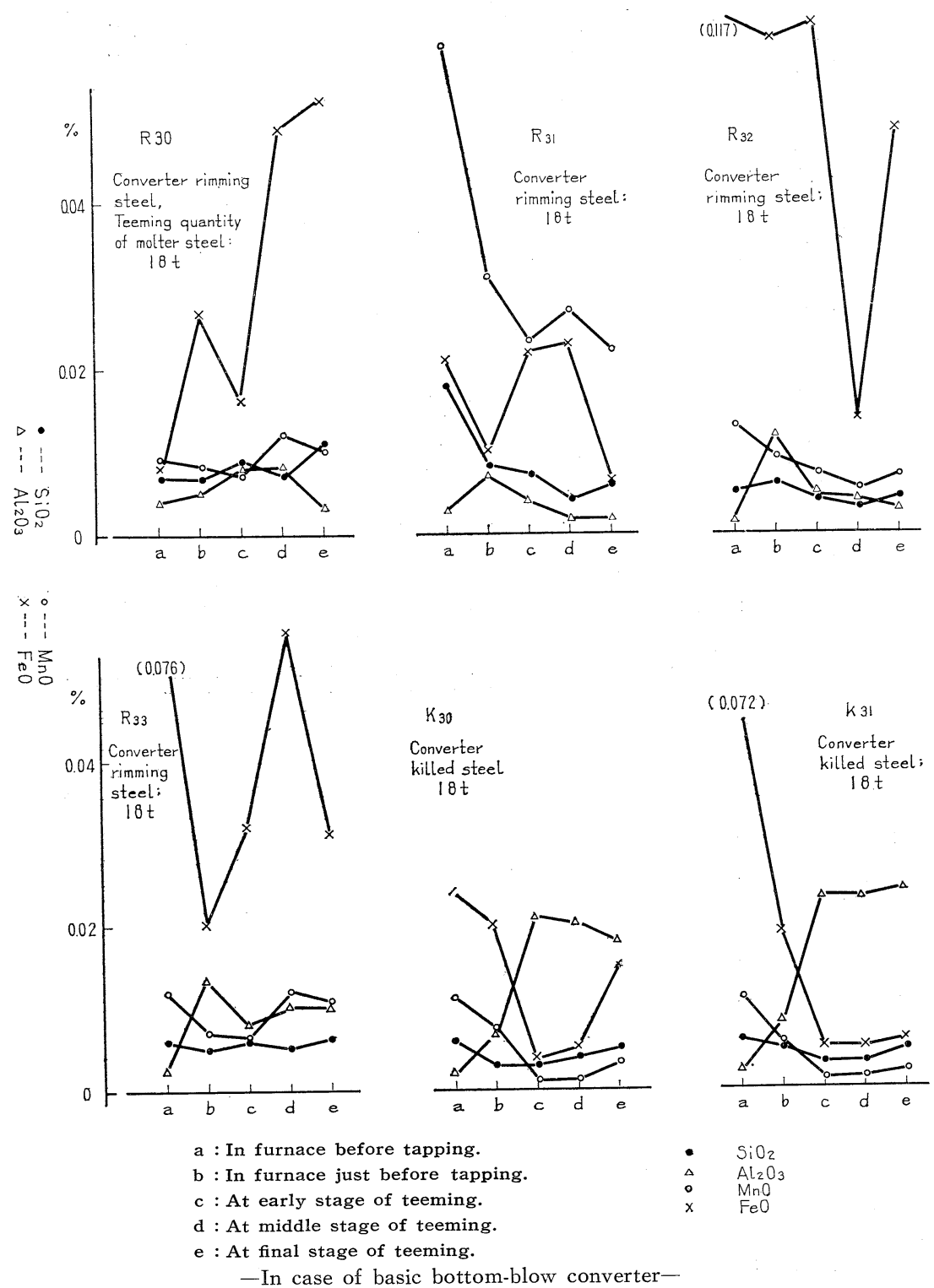

Fig. 3-A. Variation of each chemical composition of non metallic oxide-inclusion with teeming progress in stage between tapping and teeming

比をもみとめるものがある，乙れらの点から $(\mathrm{MnO}) /$ $\left(\mathrm{SiO}_{2}\right),(\mathrm{FeO}) /\left(\mathrm{SiO}_{2}\right)$ 両比の低下は明かに炉内および 取鍋脱酸に原因をもつと判断できる。

同一鋼種においてチャージ間に $\left(\mathrm{SiO}_{2}\right)$ 亿対する $(\mathrm{MnO}),(\mathrm{FeO})$ の各比の低下に著しい相異と変動をみ そめるのは, 脱酸効果の強弱のほが出鋼時の熔鋼の酸 素量の変動, 出鋼時の熔鋼流の空気酸化の程度, などに よって影響をうるがためである.また，出鋼直前の炉内 における熔鋼中の微涬の化学成分は転炉の場合に平炉の 場合に比べて不安定な傾向を示しているが，てれは転炉 で吹精する鋼種はすべて低炭素鋼であるてと，直接酸化 精錬であるための吹精条件による微妙な影響をうけるて
とに原因がある。

浮遊微㳯の量的变化：熔鋼中に浮遊する微涬の量 は, 実際にどの位かという点については取鍋内の熔鋼中 の微涬分布状態が質的量的に一様でなく, またチャージ ごとによる相異や，さらに介在物分析用の熔鋼試料を採 取する際に微㳯の一部の浮上分離をもさけられないなど のために正確に把握すること困難である.しかし, 化学 分析で求められる酸化物系介在物の量から一応推定でき ると考えた。

図一3 A, C のように, 介在物すなわち浮遊微㳯の量 は製鋼法, 脱酸法による相異を示し, 転炉の場合に量的 に多く, 鋼種間ではリムド鋼の場合にやや高目の傾向を 

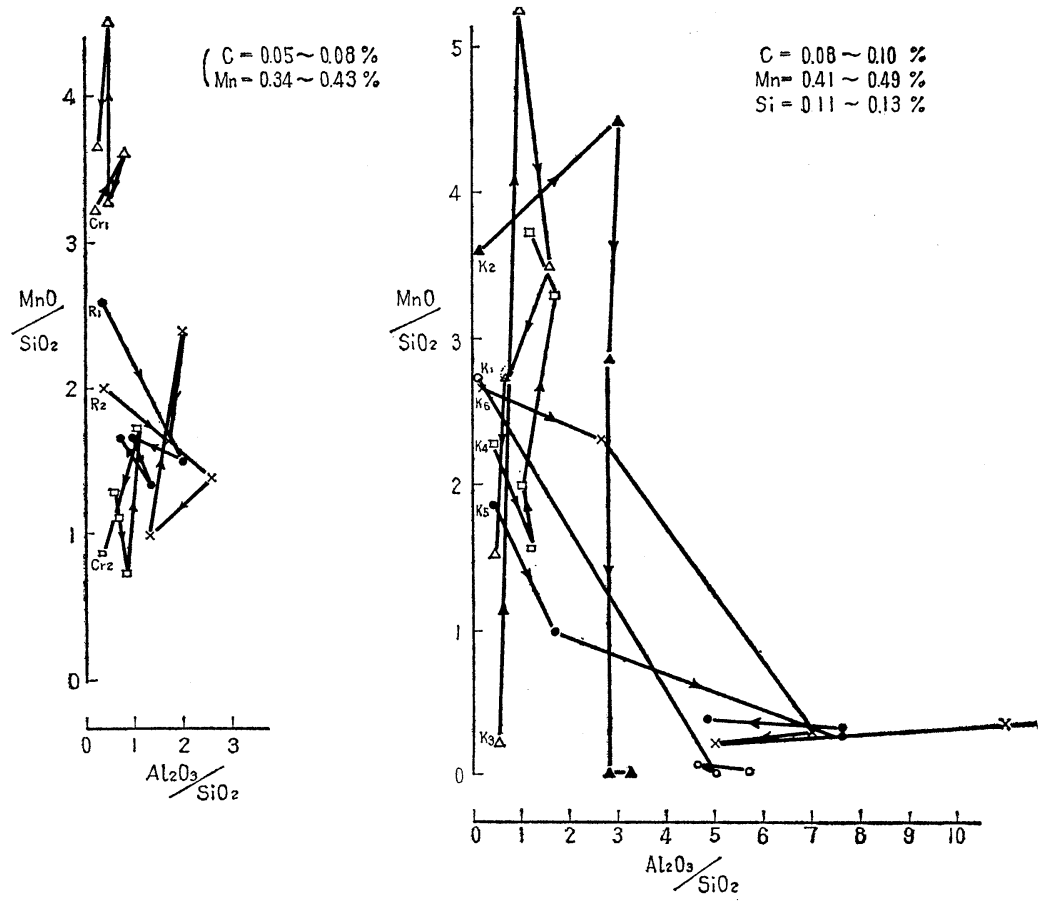

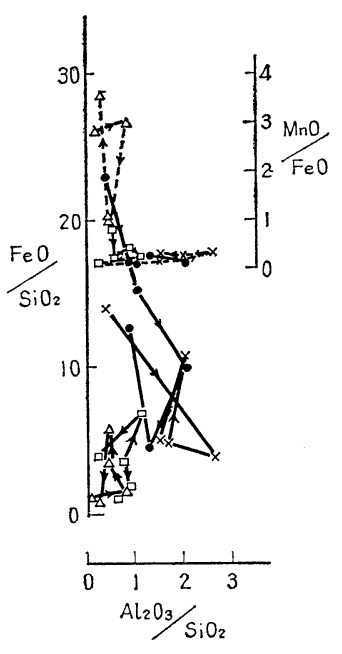

-In case of rimming converter steel-

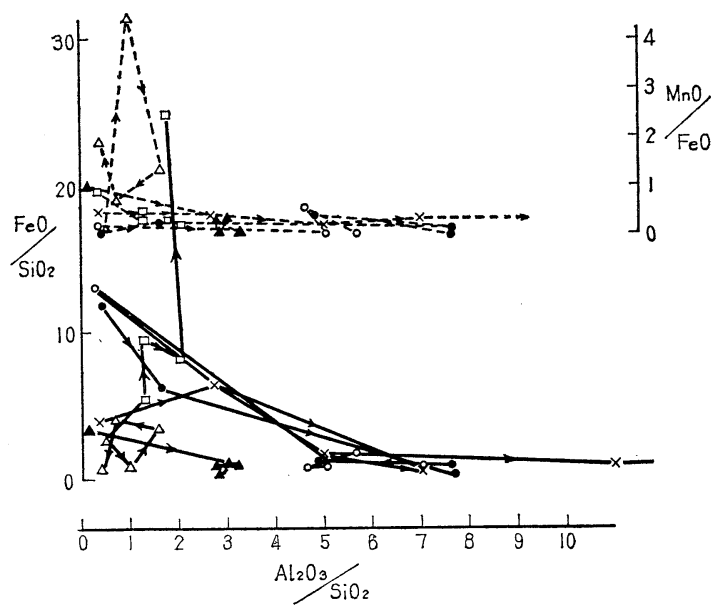

- In case of killed converter steel-

Fig. 3-B. Variation of $\mathrm{MnO} / \mathrm{SiO}_{2}, \mathrm{FeO} / \mathrm{SiO}_{2}, \mathrm{MnO} / \mathrm{FeO}, \mathrm{Al}_{2} \mathrm{O}_{3} / \mathrm{SiO}_{2}$ ratios of non-metallic oxideinclusion with pouring progress in stage between tapping and teeming

示す.

微涬成分の中の $\left(\mathrm{SiO}_{2}+\mathrm{Al}_{2} \mathrm{O}_{3}+\mathrm{MnO}\right)$ 量はりムド鋼 と低炭素のキルド鋼の両場合において大きな相異を認め ないが, $\mathrm{FeO}$ を加算した $\left(\mathrm{SiO}_{2}+\mathrm{Al}_{2} \mathrm{O}_{3}+\mathrm{MnO}+\mathrm{FeO}\right)$ 量としてはリムド鋼の場合に高目の傾向を示し，ての傾 向は転炉の場合においてととに著しい，微涬の熔鋼に対 する重量百分率は

$$
\left(\mathrm{SiO}_{2}+\mathrm{Al}_{2} \mathrm{O}_{3}+\mathrm{MnO}\right) \text { 総計 }
$$

平炣キルド鋼…0.015 0.029\% (9.7 18.8 kg/55 t ) 転炉キルド鋼…0.018〜0.031\%（3.3〜 $5.6 \mathrm{~kg} / 18 \mathrm{t})$
平炬りムド鋼 $\cdots 0.006 \sim 0.040 \%(3.3 \sim 22.0 \mathrm{~kg} / 55 \mathrm{t})$ 転炉りムド鋼…0.014〜0.034\% $(2.9 \sim 6.1 \mathrm{~kg} / 18 \mathrm{t})$

$$
\left(\mathrm{SiO}_{2}+\mathrm{Al}_{2} \mathrm{O}_{3}+\mathrm{MnO}+\mathrm{FeO}\right) \text { 総計 }
$$

平炉キルド鋼…0.010 0.032\%（5.5 20.8 kgl55 t ) 転炉キルド鋼…0.028〜0.095\% (5.0 17.6 kg/18 t ) 平炉リムド鋼 $\cdots 0.019 \sim 0.046 \%(10.4 \sim 25.3 \mathrm{~kg} / 55 \mathrm{t}$ ) 転炉りムド鋼…0.035〜0.083\%（4.7 14.9 kg/18 t ) ででく小さく，熔鋼量に対する $\left(\mathrm{SiO}_{2}+\mathrm{Al}_{2} \mathrm{O}_{3}+\mathrm{MnO}+\right.$ $\mathrm{FeO})$ 量は平炉キルド鋼で $5.5 \sim 20.8 \mathrm{~kg} / 55 \mathrm{t}$, 転炉キル ド鋼で $5.0 \sim 17.6 \mathrm{~kg} / 18 \mathrm{t}$ である.鋼の炭素量の差によ 

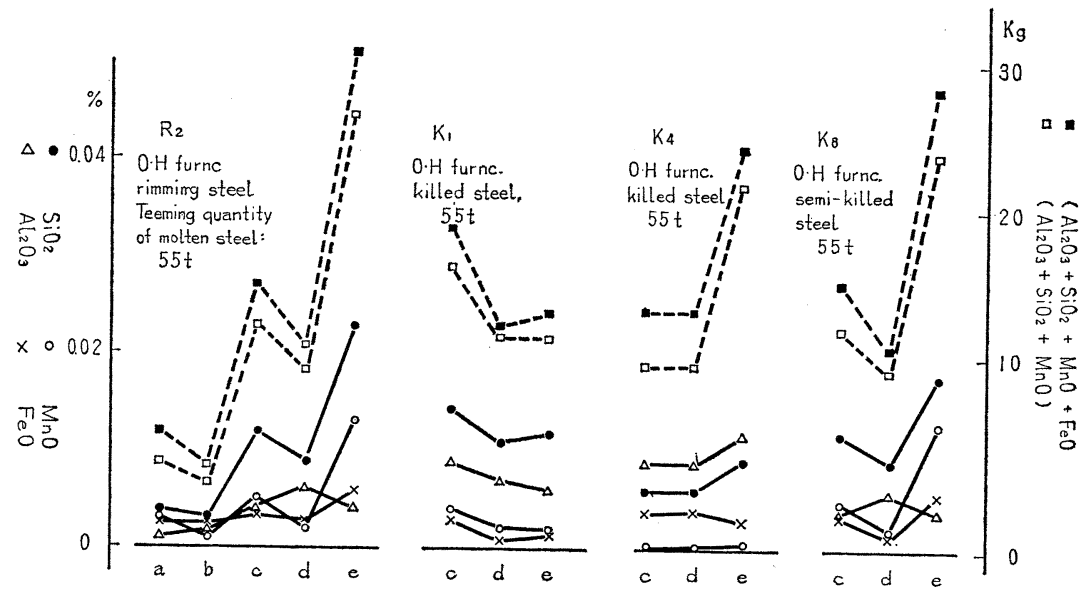

a : In furnace before adding ferromangan.

c : At first bottom plate.

b : In furnace just before tapping.

e : At third bottem plate.

d : At second bottom plate.

- In case of rimming and killed open-hearth furnc. steels-

Fig. 3-C. Variation of each chemical composition and weight of non-metallic oxide-inclusion with pouring progress in stage between tapping and teeming.

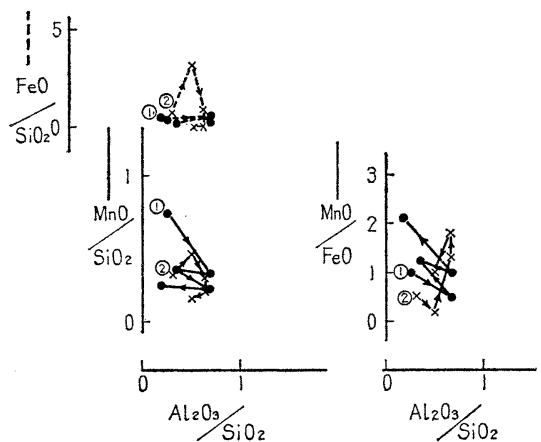

$(\mathrm{C}=0.11 \sim 0.12, \mathrm{Mn}=0.36 \sim 0.44, \mathrm{Si}=\sim 0.22 \%)$

-In case of low carbon killed open-hearth furnc. steel-
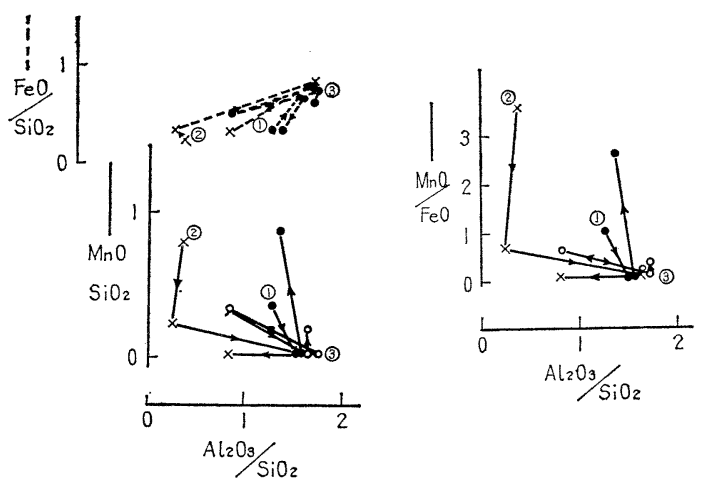

$(\mathrm{C}=0.45 \sim 0.46, \mathrm{Mn}=0.8 \sim 1.0, \mathrm{Si}=0.19 \sim 0.21 \%)$

-In case of low manganese killed open-hearth furnc. steel-

Fig. 3-D. Variation of $\mathrm{MnO} / \mathrm{SiO}_{2}, \mathrm{FeO} / \mathrm{SiO}_{2}, \mathrm{MnO} /$ $\mathrm{FeO} ; \mathrm{Al}_{2} \mathrm{O}_{3} / \mathrm{SiO}_{2}$ ratios of non-metallic oxide-inclusion with pouring progress in stage between tapping and teeming.
る相異は明瞭にはみとめられない。

平炉の場合，鋼種や炭素量の高低に無関係に微䐠は二 定盤注入時に量的に最小で三定盤注入時に増加する傾向 をみとめたが，てれは転炉の場合にみとめられなかった ことである。乙れは脱酸作業の相異にもよるが，平炉で の使用取鍋の容量が転炉の場合に比べて 3 倍ほど大き く，全注入時間も長く，乙のため熔鋼中の微㴖分布状態 に尿的差が起るのによるもので，微䐠の浮揚性に関連を もっていると考えられる.三定盤注入時に増加する微涬 量は,リムド鋼の場合に $\mathrm{SiO}_{2}, \mathrm{MnO}, \mathrm{FeO}$, キルド鋼 の場合に $\mathrm{SiO}_{2}, \mathrm{Al}_{2} \mathrm{O}_{3}$ の各成分の増加によるものであ る.

浮遊微涬中の ( $\mathrm{MnO}),(\mathrm{FeO})$ の 2 成分 : $\mathrm{FeO}-$ $\mathrm{MnO}$ 二元状態図から, $\mathrm{MnO}$ と $\mathrm{FeO}$ は全域固溶し, そ れぞれ $1780^{\circ} \mathrm{C}$ と $1370^{\circ} \mathrm{C}$ の熔融温度をもつととがわか る. $(\mathrm{MnO})$ と $(\mathrm{FeO})$ の 2 成分が遊離状態で熔錀中に 浮遊するならば， $1550^{\circ} \mathrm{C}$ 以下の熔鋼温度の条件では遊 離 $(\mathrm{MnO})$ は液相として熔鋼中に存在し難く, $\mathrm{FeO} の$ 適当量が固溶することにより初めて液相として浮遊でき るととを予想できる。 $1550^{\circ} \mathrm{C}$ で液相である固溶比率限 界は二元状態図からほほ $\mathrm{MnO}: \mathrm{FeO}=60: 40, \mathrm{MnO} /$ $\mathrm{FeO}=1.5$ であり，乙れから $\mathrm{MnO} / \mathrm{FeO}$ 比 1.5 以上の 遊離 $(\mathrm{Mn}, \mathrm{Fe}) \mathrm{O}$ は液相ではなく固相として熔鋼中に 浮遊する傾向をもつと推察される。

このような $(\mathrm{MnO}),(\mathrm{FeO})$ の 2 成分の関係は, 両 成分を比較的に多量に遊離状態で含むりムド鋼の場合に 該当するもので，介在物成分の変化からも知られる.

一方脱酸剂を多量に使用するキルド鋼の場合，遊離 $(\mathrm{MnO}),(\mathrm{FeO})$ は取鍋強制脱酸反応により減少すると 同時に $(\mathrm{Mn}, \mathrm{Fe}) \mathrm{O}$ を塩基とする珪酸塩として浮遊し， 
$(C=0.08 \sim 0.10, \quad M n=0.40 \sim 0.47, \quad S i=0.10 \sim 0.13)$

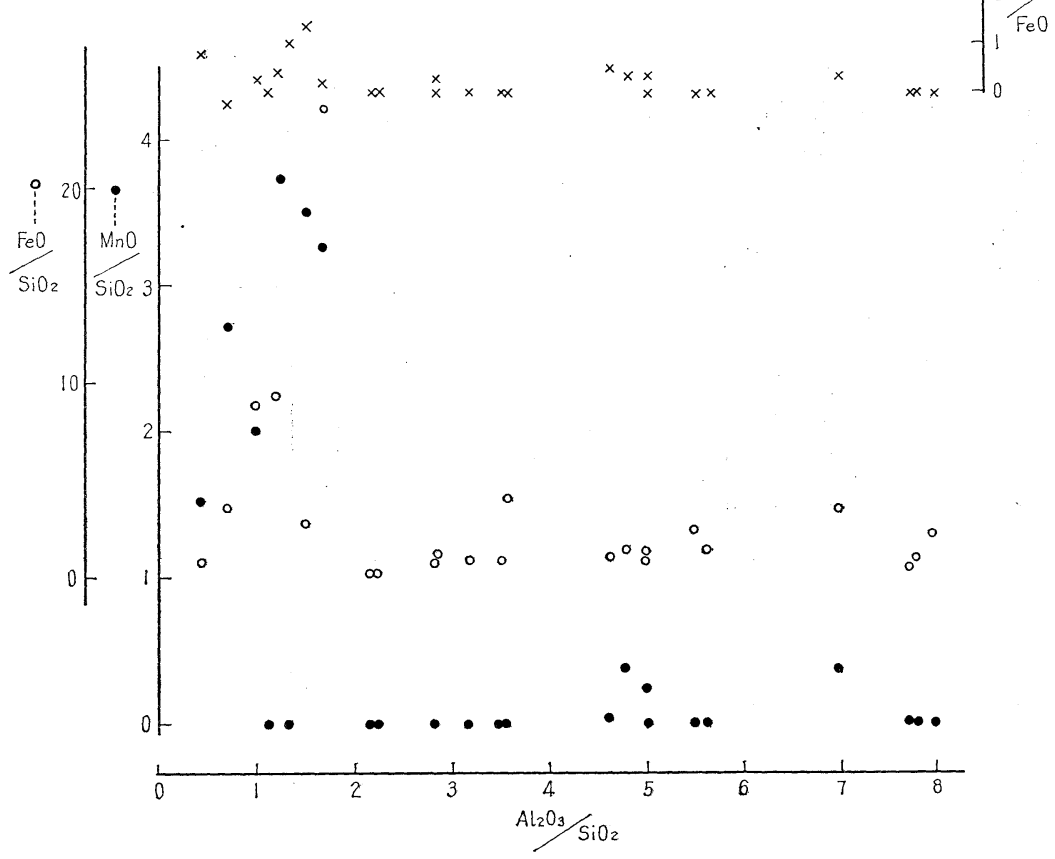

-In case of killed converter steel-
$(\mathrm{MnO})$ と $(\mathrm{FeO})$ の両成分 のすべてが遊離状態で熔鋼中 に浮遊するものでない。この 点は, 出鋼直前の炣内から注 入の期間における微涬の $\mathrm{MnO}, \mathrm{FeO}, \mathrm{Al}_{2} \mathrm{O}_{3}, \mathrm{SiO}_{2}$ の 各成分の変化を追跡した結果 からも推察される。

\section{(2) 浮遊微涬の化学組成} からみた熔蝕

このように注入中において 成分的，量的に変化する傾向 をもつ浮遊微㵏は, 混流とし て流動する熔鋼流とともに径 の細い湯道を通るので湯道棟 瓦内面への接触機会は著しく 大きいと考えられる。このよ うに運ばれる微涬の一部は棟 瓦表面に粘着し反応して熔蝕 を起させる。このため熔蝕状 態には熔鋼流中の浮遊微㳯の 化学組成によって相異を来た

すととになる。

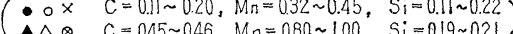

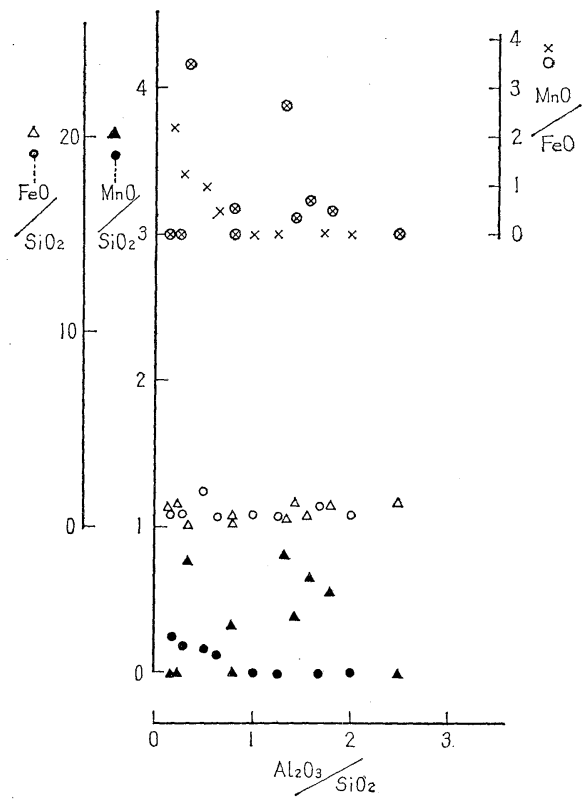

-In case of killed open-hearth furnc. steel-

Fig. 3-E. Relation between ratios of $\mathrm{MnO} / \mathrm{SiO}_{2}$, $\mathrm{FeO} / \mathrm{SiO}_{2}, \mathrm{MnO} / \mathrm{FeO}$ and ratio of $\mathrm{Al}_{2} \mathrm{O}_{3} /$ $\mathrm{SiO}_{2}$ of non-metallic oxide-inclusion in pouring stage.
浮遊微澾の一部が注入時において煉瓦に接触して侵蝕 作用をおよぼすというととの論拠は，前述した $\mathrm{Al}_{2} \mathrm{O}_{3}$ 粒 の挙動，低マンガンキルド平炉鋼の場合に鋳型内で浮上

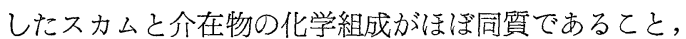
径の細い湯道を混流として流動する熔鋼流でもって運ば れること，などである。てれらの点から熔鋼流外への浮 遊微漳の分離が容易に起きて侵蝕作用を打よぼすように なると推定されるわけである。

前報1) で述べた $\mathrm{MnO}-(\mathrm{FeO})-\mathrm{Al}_{2} \mathrm{O}_{3}-\mathrm{SiO}_{2}$ 系におい て占めるリムド，キルド両鋼種の介在物分布範域，並び 飞 $\mathrm{MnO}-(\mathrm{Fe})-\mathrm{Al}_{2} \mathrm{O}_{3}-\mathrm{SiO}_{2}$ 状態図から判断されるよう に，平炉のリムド鋼では $\left(\mathrm{Al}_{2} \mathrm{O}_{3}\right) /\left(\mathrm{SiO}_{2}\right)$ 比 0.361 0.525 の煉瓦に浮遊微涬が粘着し作用をおよぼすととに より $\mathrm{MnO}-\mathrm{FeO}$ 樊土珪酸塩のガラス質熔蝕層を生成し 易い。また，脱酸の目的で少量のアルミを用いた転炉り ムド鋼では同質のガラス質熔蝕層のほかに造塊の条件に よってコランダム晶あるいはへルシナイト晶を含み，か つ煉瓦に比べて高い $\left(\mathrm{Al}_{2} \mathrm{O}_{3}\right) /\left(\mathrm{SiO}_{2}\right)$ 比をもつガラス質 熔蝕層の形成傾向をもつ。一方 $(\mathrm{MnO}),(\mathrm{FeO})$ の 2 成 分がゼロ台で微量であり, リムド鋼に比べ高い $\left(\mathrm{Al}_{2} \mathrm{O}_{3}\right)$ / $\left(\mathrm{SiO}_{2}\right)$ 比の介在物を含むキルド鋼ではコランダム晶, ヘルシナイト晶の分布する熔蝕層形成の傾向が強いと考 えられる。

キルド鋼の場合，平炉造塊に比べてアルミ使用量の多 い転炉造塊において介在物の $\left(\mathrm{Al}_{2} \mathrm{O}_{3}\right) /\left(\mathrm{SiO}_{2}\right)$ 比は広い 
範囲にわたっており, コランダム晶, ヘルシナイト晶を 含む高 $\left(\mathrm{Al}_{2} \mathrm{O}_{3}\right) /\left(\mathrm{SiO}_{2}\right)$ 比の熔蝕層を生成する傾向を強 くもつものであるが，実際に顕微鏡試験で低炭素低マン ガンの転㻏キルド鋼を注入したノズル下流の各煉瓦の熔 蝕層にコランダム晶を明瞭にみとめることができた。ま た，低炭素キルド平炉鋼に比較して $(\mathrm{MnO}),(\mathrm{FeO}) の$ 多い低マンガンキルド平炉鋼において, リムド鋼の場合 亿類似する $\mathrm{MnO}-\mathrm{FeO}$ 攀土珪酸塩のガラス質熔蝕層を 形成する傾向をもつと予想できるが，てれまた実際の検 鏡，肉眼観察結果とよく合致していた。

\section{（3）浮遊微涬の数量からみた熔蝕}

熔鋼による煉瓦の熔蝕は, 浮遊微㳯の化学組成により 左右されるのみでなく, 熔鋼中に浮遊する微䐠の量, 棟 瓦と接触して作用をおよぼす微㳯の反応量などの量的条 件にも関連が深い。化学組成からみてコランダムおよび ヘルシナイト晶を含む微㳯が作用する場合にも反応量が 少なければ $\mathrm{MnO}-(\mathrm{FeO})-\mathrm{SiO}_{2}-\mathrm{Al}_{2} \mathrm{O}_{3}$ 状態図から予想 されるコランダム界域組成の熔蝕層とならずにムライト 界域組成にとどまることになる。

注入時の熔鋼中に浮遊する微㳯の量は介在物量から推 測してきわめて僅少であるが， $\mathrm{Al}_{2} \mathrm{O}_{3}$ 粒の例の場合のよ うに粒径 $0.003 \sim 0.100 \mathrm{~mm}$ の微細粒子としては数的に 莫大な数量になる。 $(\mathrm{MnO}),(\mathrm{FeO})$ は, 珪酸塩あるい は攀土珪酸塩の化合物, またはガラス状態で浮遊しない 限り, $\mathrm{Al}_{2} \mathrm{O}_{3}$ よりも,さらに微細である分子状態で存在 して数量的にも無数に多量にのぼると考えられる.

これらの浮遊微涬の作用と熔鋼の高温で起る煉瓦熔融 の程度は, 浮遊微涬の組成, 数量, 湯道を通る熔鋼の流 動状態, 温度などによる影響をうける。したがってまた このような機構で形成する熔蝕首の一部が剥離して熔鋼 流と亡もに鋳型に流入し砂となるとすれば，砂の化学的 鉱物学的組成あるいは形態は多種多様性を示しうるであ ろう点について予想できる。

さらにまた，投入脱酸剤および熔鋼の空気による直接 酸化で生成する酸化物あるいは㳯質物は介在物に比べて 量的にはるかに多量であって, 熔鋼にまきてまれて取鍋 内で熔鋼面に浮上し切れずにそのまま浮遊するもの, 鋳 型にまで流入してゆくものも現われ，てれらによる煉瓦 の熔蝕をも軽視できないと考えられる。

\section{（4）熔鋼による不均質な煉瓦の熔蝕過程}

造塊用の粘土質煉瓦は, 約 6.0 30.0\% の遊離珪酸, 気孔, 不純分 $\mathrm{Fe}_{2} \mathrm{O}_{3}, \mathrm{CaO}, \mathrm{MgO}, \mathrm{TiO}_{2}$ やアルカリな ぞに基因するガラス質マトリックスを含み，単一な鉱物 相から構成されていない不均質な材料である。てのよう な煉瓦に熔鋼中の微涬が作用して起る熔蝕の過程は均質 な煉瓦とする場合と相当に異なったものとなるであろ う. 均質であるとする場合の反応生成物は $\mathrm{MnO}(\mathrm{FeO})$ $-\mathrm{Al}_{2} \mathrm{O}_{3}-\mathrm{SiO}_{2}$ 状態図で $\mathrm{Al}_{2} \mathrm{O}_{3}-\mathrm{SiO}_{2}$ 二元系の $\mathrm{Al}_{2} \mathrm{O}_{3} / \mathrm{SiO}_{2}$
比 0.361 の点と $\mathrm{MnO}$ あるいは $\mathrm{FeO}$ 頂点を結ぶ線で 示しうるが, 不均質な場合では $\mathrm{SiO}_{2}-\mathrm{MnO}$ および $\mathrm{SiO}_{2}$ $-\mathrm{FeO}$ 二元系の反応, $\mathrm{Al}_{2} \mathrm{O}_{3} / \mathrm{SiO}_{2}$ 比 0.84 の点と $\mathrm{MnO}$ および $\mathrm{FeO}$ 頂点を結ぶ線で示される $\mathrm{Al}_{2} \mathrm{O}_{3} \cdot 2 \mathrm{SiO}_{2}$ と $\mathrm{MnO}$ および $\mathrm{FeO}$ との反応，ガラス質マトリックスと $\mathrm{MnO}$ および $\mathrm{FeO}$ の反応などがまず進み，次いでそれ らの反応生成物間の反応, 未熔蝕部之の反応が起きて最 終的な熔蝕層の形成に進行してゆく過程を巡ると考えう る.しかし, 最終的な熔蝕層の構成鉱物相は $\mathrm{MnO}(\mathrm{FeO})$ $-\mathrm{Al}_{2} \mathrm{O}_{3}-\mathrm{SiO}_{2}$ 状態図において $\mathrm{SiO}_{2}-\mathrm{MnO}-\mathrm{Al}_{2} \mathrm{O}_{3} \cdot 2 \mathrm{SiO}_{2}$ - $\mathrm{FeO}$ の範域内にすべて包含されるようになるものと推 定される.

\section{VII. 雲状コランダム砂の成因}

微細なコランダム粒晶が集団の雲状状態で鋼の内外に 現われるいわゆる雲状コランダム砂は, その発生状況か ら前述した高アルミナのガラス質砂の場合と同様に熔鋼 中の $[\mathrm{Mn}]$ 亿よる耐火物の $\mathrm{SiO}_{2}$ 分の還元を根因として いるのでないかと考えられている砂の一種であるが, 緒 言において述べたようにその根因については充分に解明 されていない. $[\mathrm{Mn}]$ 還元反応のほかに, 脱酸反応ある いは投入 $\mathrm{Al}$ 脱酸剤の空気酸化による単なる燃焼, 熔鋼 中に浮遊する珪酸塩介在物の $\mathrm{Al}$ による還元，取鍋投入 の脱酸剤の合金表面塊に付着する易還元性酸化物の $\mathrm{Al}$ による還元などのように溶解酸素以外の酸素源がその一 因をなしているのではないかと考觉られている2〉.3.

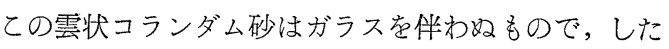
がって湯道煉瓦から剥離する熔蝕層の一部分鋳型に流れ こんで形成するとみなしうるガラス質コランダム砂とは 同視し難い種類である.浮遊微㳯が粘着した熔蝕層の剥 離を根因とするならばガラスとコランダム, あるいはま たムライトなどからなる大形の砂になる公算が大きいか らである、また，熔鋼中の $[\mathrm{Mn}]$ による粘土質酎火物 の $\mathrm{SiO}_{2}$ 分の還元反応ではコランダムを生成するてとの ない点について前述した。

著者は, 熔鋼に均一に溶解する $[\mathrm{FeO}]$ と $\mathrm{Al}$ の純脱 酸反応によって生成する $\mathrm{Al}_{2} \mathrm{O}_{3}$ 砂では熔鋼中に比較的 に一様に分散し浮遊すると考えうるのに対して, 雲状コ ランダム砂ではコランダム粒晶の集団として鋼の内外に 現われるという発生特徵や性状から熔鋼流の空気酸化と てれによって生成する $\mathrm{FeO}$ 膜に特に関連をもつのでな いかとの予想を立てた。てのような考光方から熔鋼流の 空気酸化の可能性, 空気酸化で生成する $\mathrm{FeO}$ の挙動, $\mathrm{FeO}$ の挙動と雲状コランダム砂発生の関連性について 考察した。

\section{(1) 熔鋼流の空気酸化}

平炉からの出鋼時の場合についてまず考学てみる，出 鋼時に熔鋼流は出鋼口から取鍋の間において鋼漭で被わ 
れておらず，しかも大きな表面積をもつ熔鋼面を空気に さらしながら流動するので空気酸化をうけるととが考光 られる・空気酸化が起るとすればそれによって生成する であろう $\mathrm{FeO}$ は熔鋼に溶解して溶解酸素量を高める素 因となるか，あるいはまた単に熔鋼に機械的に捲きてま れているにすぎないかの点問題となる。

この場合の空気酸化は炭素量の大小の影響を無視でき るので熔鉄の空気酸化の場合としてそれぞれの遊離エネ ルギー $\Delta \mathrm{F}^{\circ}$ ，および $\log P_{\mathrm{O}_{2}}$ を求めてみたが，註.3) 出 鋼時の条件において熔鋼流は空気酸化をうけるし，熔鋼 中の $[\mathrm{Mn}],[\mathrm{Si}]$ の空気酸化も同様に起りうると予想で きる結果がえられた。

空気酸化で熔鋼面に生成する酸化鉄は $\mathrm{FeO}$ であると 予想される。 $\mathrm{FeO}$ の熔融温度 $\left(1,370^{\circ} \mathrm{C}\right)$ からみて液状 $\mathrm{FeO}$ であり, この液状 $\mathrm{FeO}$ は熔鋼流表面に薄膜として まず形成するが，取鍋への熔鋼の流入と同時に起る激し い擋拌作用でその一部は熔鋼中に捲きてまれると考学ら れる。乙の $\mathrm{FeO}$ 薄膜の厚さ, 並びに捲きてまれる液状 $\mathrm{FeO}$ の存在状態，てれによる熔鋼の酸素量の増加など 問題であるが，てれらの点について平炉低マンガンキル ド鋼の場合について求めた取鍋投入の合金元素の過剩酸 化酸素当量註.4)を利用して概算で検討してみた。熔鋼流 は出鋼口断面積と同等の断面積をもつ円壔体状の流れを なして取鍋内に流入して, 過剩酸化の酸素当量である約 $0.25 \%$ 亿相当する量の $\mathrm{FeO}$ の薄膜で熔鋼流表面に生 成すると仮定した。

空気にさらされる熔鋼流の全表面積 $S\left(\mathrm{~cm}^{2}\right)$ は，熔鋼 流が層流と乱流のいずれであるかによって相異してくる が凮流の場合とみなして出鋼口の半径 $r(\mathrm{~cm})$, 熔鋼の全 容積 $V\left(\mathrm{~cm}^{3}\right)$ とおくと, $S=2 \pi r^{2}+2 V / r$ であるので, 実際の $15 \times 15 \mathrm{~cm}$ 矩形断面の出鋼口を径 $15 \mathrm{~cm}$ 円形断 面泪当すると仮定して実出鋼量 $57 \mathrm{t}$ 平炉で $V, S$ は,

$V \doteqdot 8,142,860 \mathrm{~cm}^{3}, S \doteqdot 2,171,750 \mathrm{~cm}^{2}$

仮に熔鋼当り酸素当量の $0.25 \%$ 亿相当する $\mathrm{FeO}$ 薄 膜を形成するとすると，乙の酸素当量は重量で 141,000 $\mathrm{g}$ であるので熔鋼流表面積当りの酸素増量 $y\left(\mathrm{~g} / \mathrm{cm}^{2}\right)$ は,

$$
y \div 141,000 / 2,171,753 \div 0.064 \mathrm{~g} / \mathrm{cm}^{2}
$$

この $y$ 值を $\mathrm{FeO}$ 増量 $y^{\prime}$ に換算すると, $y^{\prime} \div 0.29 \mathrm{~g} / \mathrm{cm}^{2}$

また $1,550^{\circ} \mathrm{C}$ における $\mathrm{FeO}$ 密度 $5.29 \mathrm{~g} / \mathrm{cm}^{3}$ を用い $\mathrm{FeO}$ 薄膜としてその厚さ $y^{\prime \prime}(\mathrm{cm})$ 亿換算すると,

$$
y^{\prime \prime} \div 0.054 \mathrm{~cm}
$$

つまり,ての概算によると, 前述の仮定の場合に空気 酸化で生成する $\mathrm{FeO}$ 薄膜の厚さは $0.5 \mathrm{~mm}$ 台となり, その全部が焀鋼中に捲きてまれて溶解すると熔鋼酸素量 を $0.25 \%$ だけ増すととになる。しかし，仮にての程度 の厚さをもつ $\mathrm{FeO}$ 薄膜が生成するとしても取鍋内に流
入する熔鋼流の激しい擋乱だけでその全部が捲きてまれ るとは考元られない，その一部のみが捲きてまれて注入 時期まで熔鋼中にとでまるであろう．また，てのように 捲きてまれる $\mathrm{FeO}$ の熔鋼中における存在状態はどうか というと，転炉りムド鋼の場合について実測でもって確 かめたように化学分析で明確にできるほど出鋼一注入期 間において溶解酸素量を 增加していない点から註.4) し て，仮に捲きてまれるものがあっても機械的に熔鋼に混 入しているにすぎないのではないかと，推察されるとて ろである。

この出鋼時の場合と条件において相異しているが，注 入時においてもノズルから注入管に流出する熔鋼流に同 様に空気酸化が起り, $\mathrm{FeO}$ 薄膜を形成し, 湯道を流動 する熔鋼流に捲きてまれる $\mathrm{FeO}$ 薄膜は鋳型にまで運ば れてゆくものもでる可能性について考光うる. ての場合 ノズルから流出する熔鋼流は乱流として流動するので空 気酸化でもって生成する $\mathrm{FeO}$ 薄膜の熔鋼への捲きてみ は一層容易であると思われる。

熔鋼流の空気酸化量については, 勿論熔鋼の空気にさ らされる表面積だけで律し壳ないし, 露出時間によって も異なってくる．さらに脱酸剤の取鍋への投入方法や投 入した脱酸剤の一部方淔接に空気にふれて燃焼するなど のために合金元素の過剩酸化酸素当量值にも問題がある がおおよその熔鋼流の空気酸化による影響については 概算結果から知りうると考えるものである.

\section{（2）雲状コランダム砂の成因について}

てのように熔鋼流に捲きこまれる $\mathrm{FeO}$ 薄膜 $(\mathrm{FeO}) t$ は, 炭素量との平衡関係を保持しながら含まれる溶解酸 素量に相当する $[\mathrm{FeO}]_{l}$ とは違い水中に浮遊する油滴と 同じような状態で存在すると想像される。

T.E. Brower, J.W. Bain, B.M. Larsen ${ }^{4)}$ は, 出鋼 時に取鍋に受鋼中に空気泡（air bubble）を熔鋼流力゙捲 きとみ，乙れが $\mathrm{Mn}, \mathrm{Si}, \mathrm{Al}, \mathrm{C}, \mathrm{Ca}$ などの取鍋内の合 金元素の過剩酸化の主因となり, 脱酸剤の歩留を低下さ すのであるとしているが，注入中に空気酸化で生成する $\mathrm{FeO}$ 薄膜の一部は空気泡と同様に熔鋼流に捲きてまれ て微細な油滴状の $(\mathrm{FeO})_{l}$ となり，兰れが過剩酸化の一 因になると同時にその浮上性が小さいととから注入湯道 を流動する熔鋼流とともに運ばれてゆくものもでてくる のでないかと考朰れる。

このように熔鋼流に，捲きてまれる微細な油滴状 $(\mathrm{FeO})_{l}$ は，注入管の上方から投入するショット $\mathrm{Al} の$ 一部と接し, $(\mathrm{FeO})_{l}$ の還元と $\mathrm{Al}$ の酸化の両反応を起 してコランダム粒を生成し, しかも溶解 $[\mathrm{FeO}]_{l}$ とは 違った機械的に混入している油滴状の $(\mathrm{FeO})_{l}$ と $\mathrm{Al}$ の 反応であるために生成するコランダムの状態は雲状にな るのでないかと考える、熔鋼中の溶解 $[\mathrm{FeO}]$ とショッ 卜 $\mathrm{Al}$ の反応では, 溶解 $[\mathrm{FeO}]$ は分子状で均一に分布 
するのでての反応で生成するコランダムでは雲状になり えないからである、また，熔鋼流の空気酸化で同様に生 成すると思われる $(\mathrm{MnO}),\left(\mathrm{SiO}_{2}\right)$ では, $(\mathrm{FeO})_{l}$ 亿比 べてそれらの生成量は圧倒的に少いので熔鋼に捲きてま れるものがでてもショット $\mathrm{Al}$ との接触機会はきわめて 少いと思われる。したがって雲状コランダム砂の主因に なりえないだろう。

雲状コランダム砂は, 下注造塊による鋼塊の外周部や 下部といった位置に特に認められるが，乙の理由は鋳型 内に流入してゆく熔鋼の流動状態並びに凝固過程での温 度分布からくる粘度増大によって強く影響をうけている がためである. 油滴状 $(\mathrm{FeO})_{l}$ とショット $\mathrm{Al}$ の反応で 生成して熔鋼流とともに鋳型内に運ばれるコランダム粒 集合体は，注入初期ではある傾きをもって流入してゆく 熔鋼とともに鋳型内壁に押しやられ易く，同時に分布範 囲の広い雲状になる傾向をもつがためであると考えられ る.もちろん，湯道を流動する間や鋳型内に流入中に熔 鋼流とともに運ばれるコランダム粒は熔鋼外に浮上して 除かれるものも多く, 雲状コランダム砂の根源となるの はそのでく一部にすぎないだろうし，雲状コランダム砂 発生の頻度が低いのもこのためであるように思われる．

要するに雲状コランダム砂は熔鋼による煉瓦の熔蝕を 原因とするものでないと推論できよう。

\section{VIII. 結 言}

前報で述べたように塩基性平炉および転炉の両製鋼造 塊による普通炭素鋼製造の場合において下注用のノズル より下流の各棟瓦の熔蝕状態, スカ厶類, 酸化物系非金 属介在物について調べた結果から，熔鋼による煉瓦熔蝕 には熔鋼中に浮遊する酸化物微泽か滵接な関係をもつて とと, 高アルミナ質砂の発生には棟瓦熔蝕が直接の原因 をなしていないてとについて予想されたが，てれらの予 想についてさらに考察した。その結果を要約すれば次の ようになる。

(1) 熔鋼中の遊離 $(\mathrm{MnO}),(\mathrm{FeO})$, マンガン珪酸塩 の煉瓦への作用, 熔鋼中の $[\mathrm{Mn}]$ による煉瓦中の $\mathrm{SiO}_{2}$. 分の還元反応, 熔鋼の高温による煉瓦表面の熔融化など によるコランダム晶の生成可能性について, 状態図, [Mn] 還元反応の遊離エネル゙ギーの計算, 並びに棟瓦熔 蝕部の検鏡結果に基づいて討究し，てれらを原因として コランダム晶は発生しえないてとを推論した。

(2) $\mathrm{Al}$ 脱酸反応で生成する $\mathrm{Al}_{2} \mathrm{O}_{3}$ 微涬粒子の熔鋼 中における挙動について, $\mathrm{Al}$ 投入使用量, 投入 $\mathrm{Al} の$ $\mathrm{Al}_{2} \mathrm{O}_{3}$ 当量の粒子数, 大きさ, $\mathrm{Al}_{2} \mathrm{O}_{3}$ 粒子の浮揚速度, 径 と浮揚性などから追究し, 脱酸反応生成物である $\mathrm{Al}_{2} \mathrm{O}_{3}$ の一部は熔鋼流とともに運ばれてノズル，注入管，定盤 の各棟瓦の表面に接して粘着しうることを推論した。

（3）熔鋼による棟瓦の熔蝕については，リムド，キ
ルドの鋼種別に出鋼一注入期における熔鋼中に浮遊する 酸化物微㳯の化学成分的量的変化を調べるととによって 浮遊微㳯の粘着と侵蝕を主因としており, その成分的量 的条件により強く左右されるものであるてとを明かにし た. 同時に熔鋼流による熔蝕の機構について推論した.

(4) $\mathrm{Al}$ キルドをなした鋼の場合に出現する高アル ミナ質砂の一種であるガラス質コランダム砂の発生原因 については，ノズルより下流の各棟瓦表面に粘着する浮 遊微㳯がその主体であり，局部的に剥離した煉瓦熔蝕層 片の一部が鋳型に運ばれるのによるととを推論した.

（5）高アルミナ質砂のもう一つの種類である雲状コ ランダム砂の発生原因については, 注入時に熔鋼流の空 気酸化で生成する液状 $\mathrm{FeO}$ の一部の熔鋼流への機械的 な捲きこみと, それと脱酸の目的で投入する $\mathrm{Al}$ の反応 にあり，棟瓦熔蝕は主因でないととを推論した．

終りに，本研究を実施するに当り御指導と御鞭莲を賜わった 日本鋼管 (株) 取締役菊池浩介博士, 同水江製鉄所副所長山下伸 六氏, 並びに本研究の発表の許可を頂いた上司の日本鋼管（株） 技術研究所長宮田聡博士, 副所長酒井重雄氏, 同次長堀川一男 博士の各位に対して 深甚の謝意を表すると共に有益なる御助言 を賜わった東京工業大学, 学長山内俊吉博士, 同学教授河嶋千 尋博士, 森谷太郎博士, 田賀井秀夫博士の各位に衷心より謝意 を表す次第である.

\section{[本文註]}

註 1）次式および次の各数值を用いて $\Delta \mathrm{F}^{\circ}$ を算出した.

(a) $[\% \mathrm{Mn}]+[\% \mathrm{FeO}]=(\mathrm{MnO})_{l}+[\mathrm{Fe}]$

$$
\begin{aligned}
& {[\% \mathrm{Mn}]+[\% \mathrm{FeO}]=}(\mathrm{MnO})_{s}+[\mathrm{Fe}] \\
& \cdots \cdots \cdot \Delta \mathrm{F}^{\circ}=-67,200+34.10 \mathrm{~T} \\
&(\mathrm{MnO})_{l}=(\mathrm{MnO})_{s} \cdots \cdots \cdots \cdot \Delta \mathrm{F}^{\circ}=10,700-5.2 \mathrm{~T}
\end{aligned}
$$

上式の $\Delta \mathrm{F}^{\circ}$ は佐野による.

(b) $1 / 2\left(\mathrm{SiO}_{2}\right)_{\text {crist. }}+[\% \mathrm{Mn}]=1 / 2\left[\% \mathrm{SiO}_{2}\right]+(\mathrm{MnO})_{l}$

$$
\begin{gathered}
\cdots \cdot \Delta \mathrm{F}^{\circ}=16,680-2.62 \mathrm{~T} \\
1 / 2\left(\mathrm{SiO}_{2}\right)_{\text {crist. }}+[\% \mathrm{Mn}]=1 / 2\left[\% \mathrm{SiO}_{2}\right]+(\mathrm{MnO})_{s} \\
\cdots \cdots \cdot \Delta \mathrm{F}^{\circ}=6,000+3.04 \mathrm{~T}
\end{gathered}
$$

佐野によれば（日本金属学会誌，4 [1] 14〜21 (1940)) 介在 物のガラス状珪酸塩としての $\mathrm{SiO}_{2}$ の活動量は, クリストバライ 卜と大きな相異をもた煌を考えられるから, 後者の遊離エネル ギーを用いても著しい誤差を生じないとしている. 上式の $\Delta \mathrm{F}^{\circ}$ を求めるに当ってこの考え方にしたがって主に同氏による次式 を利用した。

$$
\begin{aligned}
& (\mathrm{Si})_{l}+\mathrm{O}_{2 \cdot g}=\left(\mathrm{SiO}_{2}\right)_{\mathrm{crist} .} \cdots \cdots \Delta \mathrm{F}^{\circ}=-213,000+46.15 \mathrm{~T} \\
& (\mathrm{Si})_{l}=[\% \mathrm{Si}] \cdots \cdots \cdots \cdots \cdots \cdots \cdot \cdots \cdot \mathrm{F}^{\circ}=-7,000-7.78 \mathrm{~T} \\
& {[\% \mathrm{Mn}]+1 / 2 \mathrm{O}_{2 \cdot g}=(\mathrm{MnO})_{l} \cdots \Delta \mathrm{F}^{\circ}=-70,040+17.90 \mathrm{~T}} \\
& (\mathrm{Mn})_{l}+1 / 2 \mathrm{O}_{2 \cdot g}=(\mathrm{MnO})_{s} \cdots \cdots \Delta \mathrm{F}^{\circ}=-97,000+20.9 \mathrm{~T} \\
& (\mathrm{Mn})_{l}=[\% \mathrm{Mn}] \cdots \cdots \cdots \cdots \cdots \cdots \Delta \mathrm{F}^{\circ}=-9.11 \mathrm{~T} \\
& (\mathrm{MnO})_{s}=(\mathrm{MnO})_{l} \cdots \cdots \cdots \cdots \cdots \cdot \cdots \mathrm{F}^{\circ}=10,700-5.2 \mathrm{~T}
\end{aligned}
$$

(c) $1 / 2\left(\mathrm{SiO}_{2}\right)_{\text {crist. }}+[\mathrm{Fe}]=1 / 2[\% \mathrm{Si}]+[\% \mathrm{FeO}]$

(d) $\left(\mathrm{SiO}_{2}\right)_{\text {crist. }}+2[\% \mathrm{C}]=[\% \mathrm{Si}]+2 \mathrm{CO}$

$$
\cdots \cdots \Delta \mathrm{F}^{\circ}=158.440-88.3 \mathrm{~T}
$$

熔鋼中 $[\mathrm{FeO}]$ と $[\mathrm{C}]$ の反応の $\Delta \mathrm{F}^{\circ}$ のほかは佐野が与えて いる次式, ならびに (b),(c) の各式の $\Delta \mathrm{F}^{\circ}$ から上式 $\Delta \mathrm{F}^{\circ}$ 求めた.

$[\% \mathrm{FeO}]+[\% \mathrm{Mn}]=[\mathrm{Fe}]_{l}+(\mathrm{MnO})_{l}$ 


$$
\begin{array}{r}
\cdots \cdots \Delta \mathrm{F}^{\circ}=-56,500+29.10 \mathrm{~T} \\
{[\% \mathrm{FeO}]+[\% \mathrm{C}]=[\mathrm{Fe}]_{2}+\mathrm{CO} \cdots \cdots \Delta \mathrm{F}^{\circ}=6,169-12.52 \mathrm{~T}} \\
(\mathrm{MnO})_{l}+[\% \mathrm{C}]=[\% \mathrm{Mn}]+\mathrm{CO} \cdots \Delta \mathrm{F}^{\circ}=62,669-41.62 \mathrm{~T} \\
1 / 3\left(\mathrm{Al}_{2} \mathrm{O}_{3}\right)_{s}+[\% \mathrm{C}]=2 / 3[\% \mathrm{Al}]+\mathrm{CO} \\
\cdots \Delta \mathrm{F}^{\circ}=100.089-45.06 \mathrm{~T}
\end{array}
$$

註 2）六角棟瓦から定盤尻までの間の熔蝕層の容積 $V_{\text {。 }}$ は, 定盤湯道一分岐の長さ $l \doteqdot 1,400 \mathrm{~cm}$, 熔蝕層の平均厚さ $\Delta d=$ $0.3 \mathrm{~mm}$ と仮定すると,

$$
V_{c}=53,060 \mathrm{~mm}^{3} \text { (湯道径 } 40 \mathrm{~mm} \text { ) }
$$

この定盤の場合, 主分岐数が 6 であるから熔蝕層の全容積 $V_{c 6}$ は,

$$
V_{c 6}=53,060 \times 6=318,360 \mathrm{~mm}^{3}
$$

$\mathrm{Al}_{2} \mathrm{O}_{3}$ 粒子が熔蝕層全面に一様に密に分布し, 粒子間々隙が 約 $30 \%$ であるとすれば, 熔蝕層に粘着する $\mathrm{Al}_{2} \mathrm{O}_{3}$ 粒子の容積 $V_{c 6}^{\prime}$ は,

$$
V_{c 6}^{\prime}=V_{c 6} \times 0.70
$$

したがって $V_{c 6}^{\prime}$ の $V_{\mathrm{Al}_{2} \mathrm{O}_{3}}$ に対する比率は,

$$
V_{c 6}^{\prime} / V_{\mathrm{Al}_{2} \mathrm{O}_{3}} \times 100=2.94 \%
$$

註 3) $\mathrm{Fe}_{(l)}+1 / 2 \mathrm{O}_{2(g)}=\mathrm{FeO}_{(l)} \cdots \cdots \cdot \mathrm{F}^{\circ}=-39,840+3.44 \mathrm{~T}$ $\mathrm{Fe}_{x(l)}+1 / 2 \mathrm{O}_{2(g)}=\mathrm{Fe}_{x} \mathrm{O}$ (in saturated liquid) $\cdots \cdots \Delta \mathrm{F}^{\circ}=-56,830+11.94 \mathrm{~T}$

$\mathrm{Mn}(\%$ in $\mathrm{Fe})+1 / 2 \mathrm{O}_{2}=\mathrm{MnO}(l)$

$$
\cdots \cdots \Delta \mathrm{F}^{\circ}=-86,300+24.81 \mathrm{~T}
$$

註 4)

$\mathrm{Si}(\%$ in $\mathrm{Fe})+\mathrm{O}_{2}=\mathrm{SiO}_{2} \cdots \Delta \mathrm{F}^{\circ}=-206,000+53.93 \mathrm{~T}$

a. 熔鋼流の空気酸化が溶解酸素量におよぼす影響

主に塩基性転炉リムド鋼を対象にして 数チャージ分について 炉内, 出鋼, 造塊の各時期における $[\mathrm{O}]$ の变化を調べることに より出鋼時に熔鋼流の空気酸化で溶解酸素量が増加するかどう かをみた・リムド鋼の場合に重きをおいたのは脱酸作用の影響 が最小であり,空気酸化の影響について確かめ易いからである.

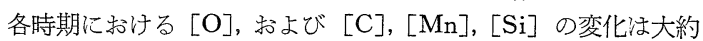

次のようである.

注入開始時の $[\mathrm{O}]$ 量は炉内 $\mathrm{Mn}$ 前の $[\mathrm{O}]$ 量の高いチャージほぞ 高い傾向を示すが，各チャージともに約 $0.04 〜 0.06 \%$ 範囲に落 着き, 直接酸化精錬の平衡式 $[\mathrm{O}][\mathrm{C}]=0.00349$ (E.B. Hughes; Blast Furnc. \& Steel Plant, 35, 677 (1947) による C= $0.06 \sim 0.08 \%$ に相灾する $[\mathrm{O}]=0.06 \sim 0.045 \%$ にほぼ同等の值 を示した.これから出鋼時において熔鋼流の空気酸化に特に基 因すると思われる 溶解酸素量の増加傾向はみとめられないと推 定できる.

b. 合金元素の取鍋内過剩酸化酸素当量

塩基性平师，底吹転炉のリムド，キルド両鋼種の若干のチャ ージについて主に出鋼一注入期間の合金元素酸化量の变化およ び同酸素当量を炉内 $\mathrm{Mn}$ 前, 出鋼時 ( $\mathrm{Mn}$ 後), 造塊時 (注入 中）の各熔鋼の化学成分変化, 並びに加炭剤, 脱酸剤の投入使 用量に基いて調べ，乙れをHerty 法による実測酸素量（溶解酸 素量）と比較することによって 合金元素の 取鍋内過剩酸化量と これに相当する過剩酸化酸素当量を求めた。

このようにして求めた塩基性平炉の低 マンガンキルド鋼の場 合の合金元素の取鍋内過剰酸化酸素当量值が $0.25 \%$ である.

\section{引用文 献}

1）佐々木. 窯協, 70 [11] 289-302 (1962)

2) M. Baeyertz. "Nonmetallic Inclusions in Steel 1947 年版

3) W.A. Hare, G. Soler. Trans. Amer. Soc. for Metals, 26, 903 (1938); B. Matuschka. J. Iron $\mathfrak{6}$ Steel Inst., 131 [1], 213 (1935); W.H. Hatfield, W.C. Newell. J. Iron \& Steel Inst., 148, 351 (1943); A.M. Portevin, R. Perrin. J. Iron \& Steel Inst. 127 [1], 153 (1933).

4) T.E. Brower, J.W. Bain, B.M. Larsen. A.I.M.E., 188, 851 (1950)

(5/8/62 受付)

\title{
金 属-磁器 封着 体 の 固着温度
}

\author{
岸 井貫 \\ （東京芝浦電気株式会社 硝子技術部）
}

\author{
Setting Point of a Hard Soldered Ceramics-to-Metal Seal \\ By \\ Toru KISHII
}

(Glass Engineering Division, Tokyo Shibaura Electric Co., Kawasaki City)

\begin{abstract}
The effects of the flow of hard solder were investigated in relation to the stress in alumina-to-kovar seal used in the envelopes of electron tubes.

Melting point of the solder was $780^{\circ} \mathrm{C}$. The ceramics and the metal were sealed together to form a bimetallic strip to measure the bending during heating or cooling.

When the sample was cooled from the temperature higher than the melting point of the soldet bending occured rather sharply at arround that point, and the curvature of the strip was approximately proportional to the contraction difference between the ceramics and the metal. More detailed examination on the relations of temperature $v s$. bending during repeated cooling showed some kind of hysteresis phenomena near the melting point of the solder.

Assuming that these were caused by the flow of the solder, by which some of the
\end{abstract}

